JST 8 (1) (2019)
JURNAL SENI TARI
Thtp://iournal.unnes.ac.id/siu/index.php/ist

\title{
Ritual pada Paguyuban Kuda Lumping Wahyu Turonggo Panuntun di Desa Legoksari Kecamatan Tlogomulyo Kabupaten Temanggung
}

\section{Putri Fatmasari Agustin ${ }^{1}$, Joko Wiyoso}

Jurusan Pendidikan Seni Drama, Tari dan Musik, Fakultas Bahasa dan Seni, Universitas Negeri Semarang, Indonesia

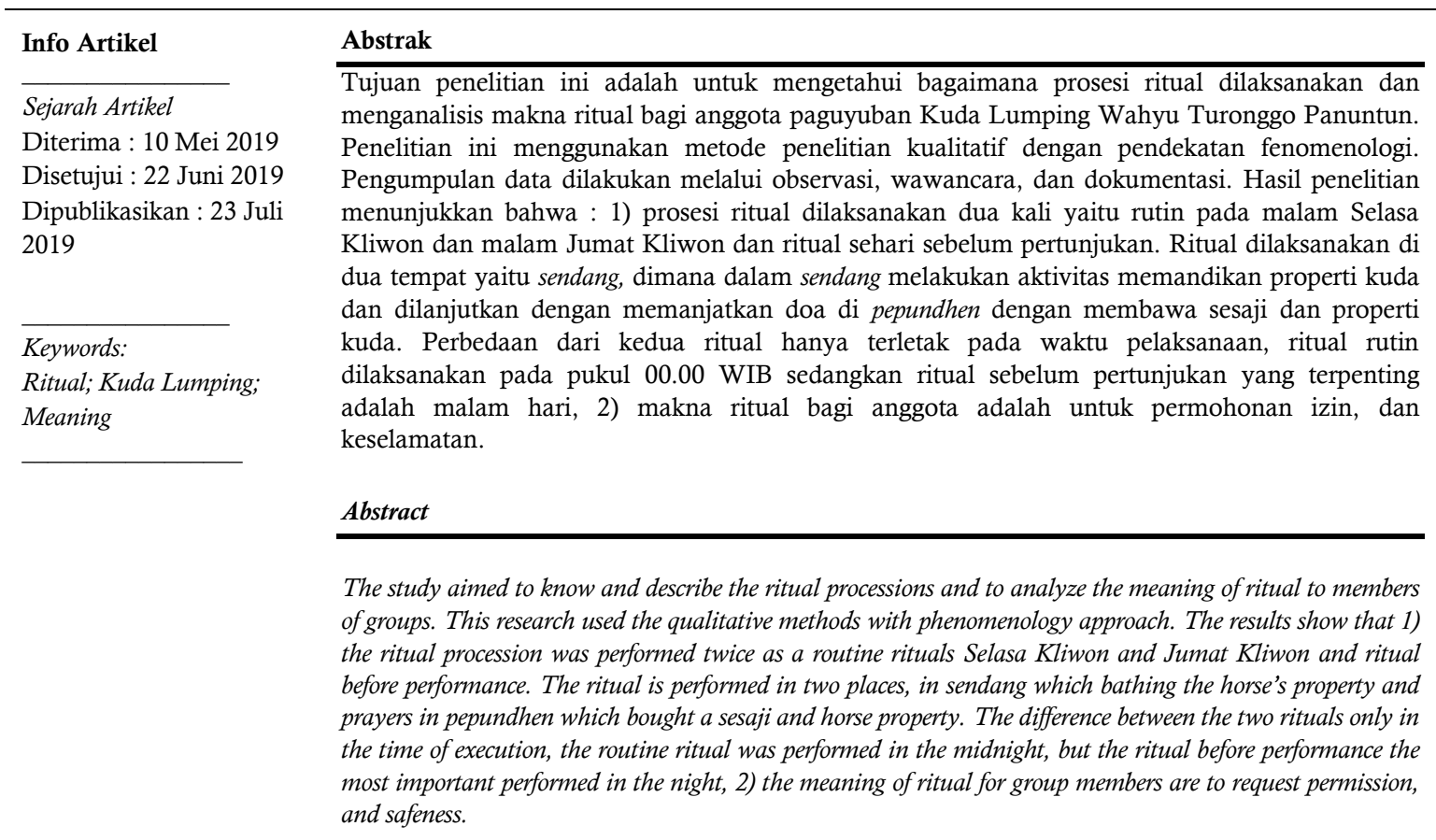

(C) 2019 Universitas Negeri Semarang

\footnotetext{
Alamat korespondensi:

Gedung B2 Lantai 1 FBS Unnes

Kampus Sekaran, Gunungpati, Semarang, 50229
}

Email : putrifatmasari.agustin@vahoo.com 


\section{PENDAHULUAN}

Kesenian $\begin{gathered}\text { Kuda } \\ \text { Lumping } \\ \text { merupakan tradisional }\end{gathered}$
kerakyatan yang masih digemari oleh
masyarakat di daerah Jawa, khususnya
Jawa Tengah. Kuda Lumping adalah tari
tradisional kerakyatan dengan ciri khas
penari berkelompok yang menari dengan
menggunakan properti anyaman bambu
yang dibentuk sehingga menyerupai
sebuah kuda dengan dilukis
menggunakan cat serta menambahkan
rambut hewan ternak seperti sapi,
kambing atau bahkan rambut kuda yang
diletakkan pada bagian kepala serta ekor
properti kuda agar menyerupai kuda
sungguhan.

Pertunjukan Kuda Lumping memiliki beragam julukan dalam setiap daerah, seperti Ebeg, Ebleg, Jaranan, Jaran Kepang, Kuda Kepang, Kuda Lumping, Reog bahkan di wilayah Bali disebut juga Sang Hyang Jaran. Kesenian Kuda Lumping banyak berkembang di daerah Temanggung. Salah satu paguyuban kesenian Kuda Lumping yang berada di Temanggung adalah paguyuban Wahyu Turonggo Panuntun yang terletak di Desa Legoksari Kecamatan Tlogomulyo Kabupaten Temanggung.

Sumaryono (2016:196) mengatakan bahwa kesenian tradisional Kuda Lumping banyak berkembang di masyarakat pedesaan atau petani. Sependapat dengan pernyataan tersebut, kesenian Kuda Lumping dapat dijumpai pada masyarakat Desa Legoksari yang mayoritas bermata pencaharian sebagai petani, masih tetap mempertahankan dan menggemari kesenian Kuda Lumping.

Sebagai salah satu dari beberapa paguyuban yang ada di Temanggung, paguyuban Wahyu Turonggo Panuntun memiliki perbedaan, yaitu bagaimana anggota paguyuban masih mempercayai dan menjalankan beberapa aktivitas yang sejak dahulu dilakukan dan masih mereka lakukan sampai saat ini. Aktivitas ini masih dilakukan turun temurun dari zaman dahulu yaitu pelaksanaan ritual.

Ritual merupakan bentuk aktivitas manusia yang masih mempercayai adanya kekuatan diluar diri manusia. Kekuatan adikodrati, baik kekuatan yang berasal dari Tuhan, maupun makhluk diluar dari manusia yaitu roh halus atau roh leluhur. Ritual dilaksanakan oleh suatu masyarakat atau individu baik sebagai sebuah bentuk penghormatan kepada roh leluhur, kepercayaan terhadap aktivitas untuk penolak bala maupun sebagai bentuk pelestarian budaya warisan nenek moyang mereka. Ritual sejatinya tidak jauh dari tata laku keagamaan (religi) atau kepercayaan.

Menurut Dhavamony (dalam Rumahuru, 2012:38), tindakan ritual dibedakan dalam empat kategori yaitu : 1) Tindakan magi yang dikaitkan dengan penggunaan bahan - bahan yang bekerja karena daya mistik; 2) Tindakan religius dan kultus para leluhur; 3) Ritual yang mengungkapkan hubungan sosial dan merujuk pada pengertian-pengertian mistik; 4) Ritual yang meningkatkan produktivitas atau kekuatan atau pemurnian dan perlindungan.

Melihat perkembangan teknologi, kemajuan pola pikir masyarakat dan segala macam perkembangan dalam era globalisasi saat ini, fenomena yang menarik dan menjadi alasan perhatian khusus oleh peneliti adalah anggota dalam paguyuban Wahyu Turonggo Panuntun yang berada di Desa Legoksari masih menjalankan serta mempertahankan tradisi sejak zaman dahulu yaitu pelaksanaan ritual memandikan properti kuda.

Faktor lain yang turut mendukung peneliti dalam melaksanakan penelitian adalah ketertarikan peneliti untuk mengetahui bagaimana prosesi yang dilaksanakan oleh anggota paguyuban Wahyu Turonggo Panuntun, dimana dalam prosesi ritual membawa serta beberapa properti atau ubarampe yang dengan sengaja dipersiapkan oleh anggota paguyuban ketika akan melaksanakan ritual serta bagaimana makna ritual bagi anggota paguyuban Wahyu Turonggo Panuntun.

Penelitian yang relevan dengan adalah penelitian yang dilaksanakan oleh Marlinda Pudyastuti dengan judul "Ritual Ngguyang Jaran di Paguyuban Jathilan Mardi Raharjo : Sebuah Ritus Peralihan" yang membahas tentang ritual ngguyang jaran atau dalam bahasa 
Indonesia memandikan properti kuda dengan diawali mengambil air di sendang yang digunakan untuk memandikan properti yang digunakan untuk pertunjukan dengan sisa air tersebut diminum oleh anggota dan prosesi diakhiri dengan pertunjukan jaran wolu.

Persamaan penelitian pada ritual yang dilaksanakan oleh paguyuban, yaitu ritual memandikan properti kuda yang masih dilaksanakan oleh anggota paguyuban. Perbedaan pada keluasan kajian, penelitian dengan objek jaran kepang dan mengkaji makna dari prosesi ritual yang dijalankan di Paguyuban Wahyu Turonggo Panuntun bagi anggota paguyuban.

Selain itu ritual yang di kaji merupakan ritual yang setiap bulan selalu dilaksanakan sebelum pertunjukan dan ritual rutin setiap bulan pada malam Selasa Kliwon dan malam Jumat Kliwon sedangkan dalam jurnal Pudyastuti mengkaji tentang ritual yang dilaksanakan setiap bulan Suro dan kajian dibatasi kepada ritual ngguyang jaran sebagai sebuah ritus peralihan.

\section{METODE}

Metode penelitian yang digunakan dalam penelitian ini adalah metode kualitatif. Metode kualitatif adalah metode penelitian yang digunakan untuk meneliti pada kondisi obyek yang alamiah dimana seorang peneliti sebagai kunci dan hasil penelitian kualitatif lebih menekankan makna dari pada generalisasi (Sugiyono, 2016:15).

Proses penelitian dilaksanakan dengan mencatat hasil penelitian untuk kemudian dilakukan pengolahan data dengan mendeskripsikan dan menganalisis hasil penelitian yang telah didapatkan. Data yang telah didapatkan dari hasil wawancara, video, foto maupun studi lapangan atau observasi langsung dengan obyek kajian kemudian dianalisis untuk selanjutnya mencari jawaban atas pertanyaan dalam rumusan masalah yang terdapat didalam penelitian.

Sumber data dalam penelitian terdapat dua yaitu sumber data primer yang diperoleh dari sesepuh atau pawang dalam paguyuban Wahyu Turonggo Panuntun, penanggung jawab dan anggota paguyuban. Sumber data sekunder berasal dari data kependudukan pemerintah desa setempat. Data dikumpulkan melalui beberapa teknik yaitu teknik wawancara, observasi dan dokumentasi. Dalam menganalisis informasi yang diperoleh, digunakan teknik keabsahan dan analisa data yang peneliti gunakan.

Triangulasi yang digunakan untuk menguji keabsahan data adalah triangulasi data yang dilakukan dengan maksud agar peneliti dapat memperoleh data yang valid dan tidak diragukan kebenarannya dengan menguji kebenaran data dengan melaksanakan penelitian melalui beberapa sumber dan beberapa data yang diperoleh, kemudian triangulasi teknik metodologis yaitu penggunaan sejumlah teknik dalam suatu penelitian.

Penggunaan beberapa teknik dalam penelitian dimaksudkan agar data yang diperoleh mendekati kebenaran dari beberapa sumber yang telah diteliti dengan menggunakan teknik yang berbeda, selanjutnya yaitu triangulasi teori yaitu data yang telah diperoleh kemudian dibahas dengan teori yang digunakan dalam penelitian. Data yang telah dikumpulkan kemudian dianalisis dengan mereduksi data, menyajikan data dan kemudian menarik kesimpulan dari data yang telah dibahas.

\section{HASIL DAN PEMBAHASAN}

\section{Sejarah Kesenian Kuda Lumping Paguyuban Wahyu Turonggo Panuntun}

Paguyuban Wahyu Turonggo Panuntun berdiri sejak awal tahun 2005 dan merupakan paguyuban yang telah mengkolaborasikan pertunjukan Kuda Lumping dengan kesenian Bali. Harapan dari pemberian nama paguyuban agar paguyuban Wahyu Turonggo Panuntun menjadi paguyuban tuntunan bagi paguyuban Kuda Lumping lainnya.

Pada pertunjukannya, cerita yang dipertunjukkan merupakan kisah perjuangan dari seorang pemimpin pasukan berkuda yang dikenal dengan 
sebutan landang dalam memperebutkan cinta gadis impiannya dengan tokoh jahat yaitu Leak.

Dahulu, cerita dari kesenian Kuda Lumping mengisahkan tentang perjuangan dari sesepuh dalam membuka lahan atau mbabad alas yang digunakan untuk pemukiman dengan menggunakan kuda atau jathil.

\section{Sejarah Prosesi Ritual}

Ritual sejatinya telah dilaksanakan oleh masyarakat di Desa Legoksari sejak zaman dahulu. Dahulu, seluruh masyarakat selalu melaksanakan ritual jika akan mengadakan hajatan seperti pernikahan, sunatan maupun untuk keselamatan diri pribadinya. Ritual memandikan properti kuda telah dilaksanakan sejak dahulu sebelum adanya paguyuban-paguyuban yang ada di dusun Lamuk Gunung. Dahulu, Kuda Lumping yang dipentaskan merupakan representasi dari cerita perjuangan, cerita bagaimana danyang atau orang zaman dahulu membuka lahan untuk pemukiman dan dianggap sangat sakral kehadirannya.

Pertunjukan Kuda Lumping dianggap sangat sakral dan segala macam properti yang digunakan untuk pertunjukan dibawa ke pepundhen desa dan dimandikan di sendang yang dekat dengan pepundhen desa. Memandikan properti kuda di sendang bukanlah tanpa maksud tertentu. Sendang tersebut merupakan sumber perairan pertama bagi warga dusun Lamuk Gunung yang telah memberikan penghidupan bagi masyarakat dan tanaman milik warga sekitar.

Dimandikannya properti kuda di sendang merupakan salah satu cara bagi anggota dalam mengucapkan rasa syukur terhadap Tuhan dan leluhur yang telah membuka penghidupan di desa yang dahulunya merupakan hutan belantara dan telah mewariskan kesenian Kuda Lumping yang merupakan representasi dari bagaimana leluhur dahulu membuka lahan untuk pemukiman mereka saat ini.

\section{Pertunjukan Kuda Lumping \\ Pertunjukan kuda lumping dibagi menjadi tiga tahap yaitu sebelum}

pertunjukan, saat pertunjukan dan setelah pertunjukan.

\section{Sebelum Pertunjukan}

Penari mempersiapkan diri dengan merias wajah mereka masing-masing. Jenis rias yaitu gagah yang berkarakter galak. Alat rias yang dipakai diantaranya adalah siwit berwarna hitam dan kuning tua serta glitter, kuas yang digunakan untuk mengaplikasikan siwit dan pensil alis untuk menggambar pola alis dan godeg.

Jumlah anggota pada setiap kali pementasan yaitu 17 penari Kuda Lumping, 2 penari Pendet, 1 penari topeng Jauk, 1 penari Bagusan, 2 penari Leak, 2 penari Barong, 1 penari topeng Monyet dan 1 penari Cendrawasih. Pengrawit berjumlah 15 orang dan sudah termasuk penyanyi. Sementara penari sedang mempersiapkan diri, beberapa tim pendukung mempersiapkan kostum dan gamelan yang akan digunakan beserta properti yang dipakai dalam pertunjukan.

\section{Saat Pertunjukan}

Pertunjukan Kuda Lumping di paguyuban Wahyu Turonggo Panuntun mengisahkan tentang perebutan seorang wanita oleh Rangda atau Leak dengan pemimpin dari pasukan berkuda yang disebut dengan Landang. Perebutan oleh dua Leak yaitu Leak Merah dan Leak Putih yang mengisahkan tokoh yang jahat dengan seorang pemimpin prajurit berkuda yang disebut sebagai Landang yang merupakan musuh dari Leak untuk memperebutkan gadis impian mereka.

Perebutan tersebut berujung kepada permusuhan dari kedua belah pihak. Hingga datangnya seorang raja dari wilayah mereka datang sebagai pihak netral untuk memberikan jalan tengah kepada permusuhan keduanya tersebut dan untuk menyelesaikan permusuhan dan peperangan diantara keduanya maka sang raja mendatangkan Barong untuk mengusir roh jahat yaitu Leak atau Rangda.

Durasi pertunjukan Kuda Lumping paguyuban Wahyu Turonggo Panuntun berkisar antara 1-1,5 jam dalam setiap kali pementasan. Ragam dari gerak tersebut antara lain Lepas Kuda, Ngirig, 
Kentrik, Minuman, Timpang Kerep 1, Lampah Balik, Congklangan, Sembahan, Tari Jauk, Kiprahan, Teposan, Timpang Kerep, Tari Pendet, Perang Massal, Tari Cendrawasih, Mendeman, Tari Bagusan, Kiprah Baris, Congklang, Tari Leak, Tari Barong, Kuda Lepas.

\section{Setelah Pertunjukan}

Tahap akhir dalam pementasan, seluruh pemain yang bertugas dalam pertunjukan mempersiapkan diri untuk mengemas barang yang dibawa saat pertunjukan. Pemain, biasanya penari masih ada dalam kondisi trance, atau dalam kondisi kerasukan. Pawang atau sesepuh mengobati pemain yang sedang dalam kondisi trance yang masih berada di arena pertunjukan.

Ketika pawang atau sesepuh mengobati penari yang mengalami trance tidak mengucapkan doa atau mantra khusus untuk melepaskan roh yang masuk ke tubuh penari, melainkan berkomunikasi. Ngateman mengajak penari yang dengan kondisi sedang trance untuk berkomunikasi dan mempertanyakan maksud dan tujuan mengapa masuk ke tubuh penari Kuda Lumping, tak jarang apabila penari tidak ada yang mengalami trance, pawang sengaja mengundang roh untuk masuk ketubuh penari agar pertunjukan menjadi ramai.

\section{Prosesi Ritual}

Prosesi ritual dilaksanakan melalui beberapa tahapan. Anggota paguyuban melaksanakan ritual memandikan kuda sebanyak 2 kali yaitu ritual secara rutin dilaksanakan dan ritual yang dilaksanakan satu hari sebelum pertunjukan Kuda Lumping. Beberapa aspek yang diamati dalam ritual meliputi tempat pelaksanaan ritual atau upacara, saat upacara atau ritual berlangsung, benda dan alat yang digunakan serta orang-orang atau pelaku dalam ritual.

Terdapat dua tempat pelaksanaan ritual rutin, yaitu berada di sendang atau masyarakat sering menyebutnya dengan istilah kali, dan berada di pepundhen desa. Jarak antara sendang dan pepundhen sekitar 200 meter. Dalam setiap tempat ritual memiliki aktivitas yang berbeda.
Pada saat ritual di sendang, dilaksanakan ritual memandikan properti kuda di air pancuran sendang dan ketika sampai di pepundhen, hanya memanjatkan doa kepada danyang desa.

Ritual rutin dilaksanakan dengan anggota paguyuban berkumpul dirumah salah satu anggota pada malam hari sebelum pukul 00.00 WIB. Pemilihan hari dan waktu tersebut dikarenakan anggota percaya bahwa malam Selasa Kliwon dan malam Jumat Kliwon merupakan hari yang suci dan hari yang baik untuk masyarakat Jawa pada khususnya dalam melaksanakan ritual dan pemilihan waktu pukul 00.00 WIB tersebut merupakan waktu yang tepat bagi anggota untuk meminta izin oleh danyang desa.

Pemilihan waktu selain berdasar dengan kepercayaan anggota bahwa waktu tersebut merupakan waktu yang tepat bagi anggota untuk bermunajat ke pepundhen, pemilihan waktu tersebut merupakan waktu yang tepat karena seluruh anggota yang mayoritas merupakan seorang pekerja yang bekerja pada sektor pertanian telah berada di rumah dan tidak sedang melakukan aktivitas pekerjaan mereka.

Selain itu, pada pukul 00.00 WIB merupakan ujung dari hari dan diharapkan kesakralan dan kekhidmatan pemanjatan doa dari prosesi ritual dapat anggota peroleh. Lebih rincinya, aktivitas di sendang dan pepundhen adalah sebagai berikut :

\section{Memandikan Kuda di Sendang}

Anggota yang ikut dalam prosesi ritual berangkat ke sendang dengan berjalan kaki bersama-sama. Sepanjang perjalanan menuju ke sendang berbicara dan bersenda gurau layaknya sedang bersantai didalam rumah. Hal itu dilaksanakan agar mereka tetap dalam keadaan apapun dapat saling bahumembahu untuk menolong seluruh anggota yang membutuhkan bantuan, tetap menjaga kekompakan dan menjaga kekerabatan mereka baik disaat pertunjukan maupun pada hari biasa saat menjalankan aktivitas mereka masingmasing. 
Saat sampai di sendang, mereka mengucapkan salam "assalamualaikum" dan mulai hening tidak banyak berbicara seperti saat sedang berjalan menuju ke sendang. Mereka menyiapkan segala macam peralatan yang dibutuhkan ketika berada di sendang. Pawang atau sesepuh meletakkan sesaji di tempat khusus untuk sesaji, yaitu di sebelah pancuran sendang yang merupakan tempat khusus untuk peletakan sesaji.

Sesaji yang diletakkan adalah sesaji kembang setaman dan kembang dorang. Sesaji dupa dan kemenyan dibakar bersebelahan dengan sesaji bunga. Ketika berada di tempat sakral, rambut kuda tersebut di asap dengan menggunakan kepulan asap hasil pembakaran dupa dan kemenyan yang telah dipanjatkan doa oleh pawang.

Setelah kuda telah di asap dengan bakaran dupa dan kemenyan, kuda kemudian dibawa ke pancuran air. Ditempat pancuran air tersebut kuda dimandikan secara bergantian oleh pawang atau sesepuh paguyuban. Pada prosesi memandikan kuda di sendang, pawang atau sesepuh memanjatkan doa, meminta restu untuk selalu diberi keselamatan. Rambut kuda yang telah terkena asap pembakaran dupa dan kemenyan memberikan makna bahwa agar doa dan segala keinginan yang dipanjatkan serta danyang desa dapat masuk ke properti kuda.

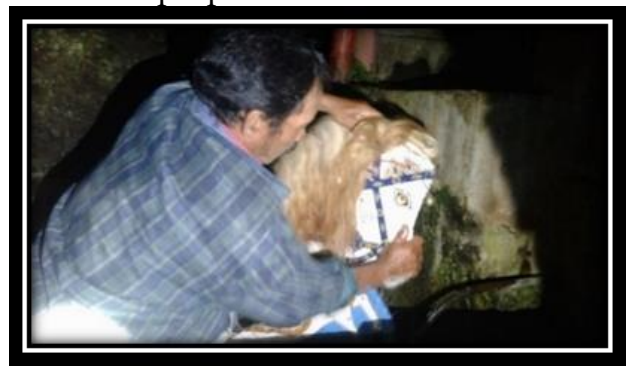

Foto 1. Ritual Memandikan Properti Kuda (Sumber: Agustin, 1 Maret 2019)

\section{Memanjatkan Doa di Pepundhen}

Prosesi memandikan kuda di sendang telah selesai, ritual dilanjutkan dengan memanjatkan doa di pepundhen. Seluruh anggota yang ikut melaksanakan prosesi berjalan menuju pepundhen desa dengan perilaku yang sama seperti pada saat berjalan menuju ke sendang, bercanda dan membicarakan seputar aktivitas mereka pada pagi hari.

Prosesi dilaksanakan dengan meletakkan sesaji disebelah batu besar yang berada di pepundhen desa. Kemudian pawang atau sesepuh mulai memanjatkan doa dengan menyalakan dupa dan kemenyan. Doa yang dipanjatkan merupakan doa untuk meminta keselamatan untuk seluruh anggota paguyuban. Ketika pawang atau sesepuh sedang menyalakan kemenyan, aktivitas tersebut merupakan tanda bahwa roh sedang diundang untuk hadir dan mendengarkan doa, keinginan dan maksud mereka.

Pada saat kemenyan yang dibakar telah habis dan api hasil pembakaran tersebut telah mati, seluruh anggota mengikuti prosesi berdoa dengan khidmat dengan menundukkan kepala mereka. Menundukkan kepala dan tidak berbicara pada saat berdoa merupakan aktivitas agar mereka dapat mendapatkan kekhusyuan ketika berdoa.

Hal tersebut juga bukti kesungguhan mereka mendatangi pepundhen desa dengan niat baik untuk melaksanakan ritual dalam kesenian yang mereka jaga sampai saat ini. Selain itu, perilaku tersebut merupakan salah satu cara bagi mereka untuk menghormati yang lebih tua yaitu sesepuh atau roh leluhur mereka. Menjunjung tinggi nilai tradisi dan saling hormat menghormati kepada sesama, termasuk kepada roh leluhur sudah menjadi bagian dari kehidupan anggota paguyuban Wahyu Turonggo Panuntun.

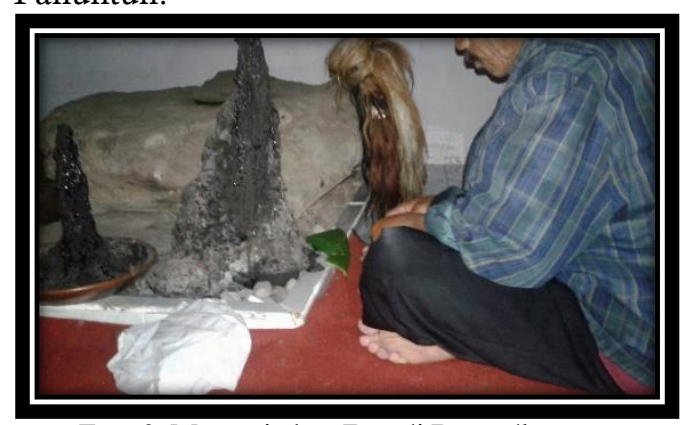

Foto 2. Memanjatkan Doa di Pepundhen (Sumber : Agustin, 1 Maret 2019) 


\section{Benda dan Alat Upacara}

Sesajen yang disiapkan dalam ritual rutin adalah kembang dorang. Sebutan bunga dorang tersebut untuk bunga jenis bunga mawar merah, bunga mawar putih, bunga kenanga dan bunga kantil. Selain kembang dorang, disediakan pula kembang setaman, dupa dan kemenyan. Selain itu adalah properti kuda yang paling utama.

\section{Orang atau Pelaku Upacara}

Pada prosesi ritual, tidak seluruh anggota paguyuban mengikuti prosesi ritual tersebut, hanya perwakilan anggota yang berkisar antara 5-10 anggota dan pemimpin ritual yaitu pawang atau sesepuh paguyuban Ngateman.

\section{Ritual Sebelum Pertunjukan}

Pada ritual sebelum pertunjukan, tidak terdapat perbedaan yang signifikan. Properti, sesaji dan tata cara yang dilaksanakan sama dengan ritual yang dilaksanakan rutin. Perbedaan ritual sebelum pertunjukan hanya pada waktu pelaksanaan. Pelaksanaan ritual sebelum pertunjukan dilaksanakan satu hari sebelum pertunjukan akan dilaksanakan dan dilaksanakan pada malam hari.

Tidak seperti ritual yang rutin dilaksanakan, ritual sebelum pertunjukan tidak harus dini hari dilaksanakan. Akan tetapi, ritual tetap dilaksanakan pada malam hari, karena menyesuaikan dengan kegiatan para anggota dan pada malam hari suasana lebih khidmat dan lebih tenang ketika akan memanjatkan doa di sendang dan di pepundhen desa.

Pada saat pertunjukan, sesaji yang digunakan berbeda dengan sesaji pada saat ritual. Sesaji yang dibutuhkan antara lain kembang dorang, kembang setaman, dupa, kemenyan, juwadah pasar (buahbuahan dan makanan ringan), bubur merah putih, wedang 7 werno (kopi legi, kopi pait, teh legi, teh pait, wedang putih, wedang santen, wedang dawet), kelapa atau degan, kacang-kacangan (kacang panjang), dan sego pecel.

Makna dari setiap sesaji antara lain kembang dorang bermakna mengangkat atau menjunjung dari sing mbaurekso deso atau yang menjaga desa yaitu danyang desa, kembang setaman diambil dari kata terakhir yaitu man atau aman yang diharapkan dapat mendapatkan keselamatan dan keamanan dalam berkesenian di paguyuban.

Juwadah pasar yang berisi makanan yang dibeli dipasar, diantaranya ada makanan ringan atau snack, pisang dan kue-kue kering. Jajanan pasar merupakan simbol dari kebersamaan. Hal itu karena isi dari sesaji juwadah pasar yang beraneka ragam dan dijadikan satu dengan sebutan juwadah pasar. Kebersamaan merupakan salah satu hal yang menjadi alasan dari anggota paguyuban dalam berkesenian yaitu agar seluruh anggota tetap saling menjaga kebersamaan dan rasa persaudaraan.

Wedang 7 werno yang terdiri dari kopi manis dan kopi pait, teh manis dan teh pait, air putih, air santan, dan dawet merupakan simbol bahwa dalam kehidupan haruslah seimbang antara bahagia yang disimbolkan dengan minuman manis dan juga dawet dan sedih yang disimbolkan dengan minuman pait dan air santan yang hambar. Sego pecel yang berisi beraneka ragam sayuran dan ikan asin sebagai lauk merupakan simbol kesejahteraan, yang diharapkan seluruh anggota paguyuban Wahyu Turonggo Panuntun agar tetap hidup sejahtera dalam kehidupan berkesenian mereka.

Kacang panjang merupakan simbol bahwa hendaknya kita harus berfikir panjang jika akan berbuat sesuatu, seperti halnya pada anggota paguyuban harus berfikir secara matang ketika akan memberikan inovasi baru agar paguyuban tetap memberikan kreativitas dan daya tarik baru.

Bubur Merah Putih, bubur berwarna merah merupakan simbol dari rasa semangat mereka dalam berkesenian dan bubur berwarna putih merupakan simbol dari rasa ketulusan mereka untuk melestarikan tradisi dari leluhur. Kelapa atau degan merupakan simbol dari minuman kegemaran roh leluhur. Terkadang digunakan sebagai atraksi ketika penari mengalami trance.

Hasil temuan dibahas menggunakan teori dalam penelitian. Kuda Lumping merupakan kesenian tradisional kerakyatan yang berkembang pada 
masyarakat agraris dan merupakan peninggalan dari zaman pra sejarah. Dhavamony (dalam Rumahuru, 2012:38) mengatakan empat kategori dalam ritual, aktivitas ritual pada paguyuban Wahyu Turonggo Panuntun termasuk dalam beberapa kategori menurut Dhavamony.

Tindakan ritual yang dilaksanakan oleh anggota paguyuban Wahyu Turonggo Panuntun menggunakan beberapa benda yang dianggapnya dapat bekerja karena daya magisnya. Penggunaan benda seperti sesaji dupa dan kemenyan pada saat ritual dilaksanakan yang dipercaya dapat mengundang roh leluhur untuk datang dan mendengarkan hajat mereka termasuk kategori ritual menurut Dhavamony dengan praktik tindakan magi yang dikaitkan dengan penggunaan bahan yang bekerja karena daya mistik.

Kategori kedua yaitu tindakan religius dan kultus para leluhur. Ritual yang dilaksanakan merupakan warisan tradisi dari nenek moyang secara turun temurun dan bukan aktivitas yang sembarang dilaksanakan. Mereka memiliki kepercayaan penuh terhadap leluhurnya agar dapat memberikan keselamatan bagi mereka. Tindakan ritual yang dilaksanakan tidak hanya sebatas aktivitas rutin yang dilaksanakan sejak dahulu sampai saat ini.

Kepercayaan anggota pada kekuatan leluhur untuk dapat membantu mereka dalam setiap berkesenian dan melindungi anggota dari mara bahaya merupakan kategori ritual yang digunakan untuk meningkatkan produktivitas atau kekuatan atau pemurnian dan perlindungan. Kehadiran simbol dalam setiap ritual melengkapi tindakan ritual anggota paguyuban Wahyu Turonggo Panuntun

\section{Makna Ritual Bagi Anggota Paguyuban Wahyu Turonggo Panuntun}

\section{Permohonan Izin}

Ritual dilaksanakan secara rutin setiap bulan, lebih tepatnya pada malam Selasa Kliwon dan malam Jumat Kliwon serta sebelum pementasan merupakan ritual yang dilaksanakan untuk permohonan izin kepada danyang desa, permohonan izin atau berpamitan dengan danyang desa untuk melakukan aktivitas yang berkaitan dengan kesenian, khususnya Kuda Lumping yang merupakan kesenian warisan dari leluhur. Permohonan izin juga merupakan aktivitas yang dilaksanakan oleh anggota agar danyang desa selalu merestui mereka apabila akan melaksanakan pertunjukan Kuda Lumping.

\section{Keselamatan}

Ritual dilaksanakan oleh anggota paguyuban Wahyu Turonggo Panuntun memiliki makna keselamatan. Keselamatan baik sebelum dan setelah pertunjukan maupun keselamatan ketika seluruh anggota pada paguyuban Wahyu Turonggo Panuntun melaksanakan pertunjukan Kuda Lumping. Selain itu, mereka meyakini bahwa keselamatan juga akan mereka dapatkan ketika pada pertunjukan disaat anggota mengalami trance.

Anggota paguyuban percaya bahwa danyang desa dapat melindungi mereka dari roh leluhur yang jahat yang dapat mencelakakan mereka walaupun sudah tidak melaksanakan pertunjukan Kuda Lumping. Selain itu, keselamatan dapat mereka peroleh dari pelaku atau orang yang dengan sengaja akan mencelakai atau memasang roh jahat untuk mengikuti anggota paguyuban.

\section{SIMPULAN}

Berdasarkan hasil penelitian dapat disimpulkan bahwa kesenian Kuda Lumping di Desa Legoksari telah berkembang sejak zaman dahulu dan sampai saat ini telah mengalami perkembangan cerita, khususnya pada paguyuban Wahyu Turonggo Panutun. Paguyuban Wahyu Turonggo Panuntun merupakan paguyuban Kuda Lumping yang masih melaksanakan ritual memandikan properti kuda di sendang dan pepundhen desa.

Prosesi ritual dilaksanakan dengan memandikan properti kuda di sendang dengan membawa serta sesaji kembang dorang dan kembang setaman. Prosesi dilanjutkan dengan memanjatkan doa di 
pepundhen desa. Ritual yang dilaksanakan rutin setiap malam Selasa Kliwon dan malam Jumat Kliwon serta sehari sebelum melaksanakan pertunjukan. Ritual dilaksanakan pada malam hari dengan prosesi yang sama pada saat ritual rutin maupun ritual sehari sebelum pertunjukan.

Makna ritual bagi anggota paguyuban Wahyu Turonggo Panuntun adalah sebagai permohonan izin kepada danyang desa, untuk keselamatan para anggota pada saat pertunjukan Kuda Lumping maupun diluar dari pertunjukan Kuda Lumping.

\section{DAFTAR PUSTAKA}

Rumahuru, Y. C. dkk. (2012). Ritual Ma'atenu Sebagai Media Konstruksi Identitas Komunitas Muslim Hatuhaha Di Pelauw Maluku Tengah. Jurnal Kawistara, 2(1), 36-47. Diunduh dari

Sugiyono. 2009. Merode Penelitian Kualitatif dan $R \& D$. Bandung : Alfabeta.

2016. Metode Penelitian Pendidikan. Bandung : Alfabeta.

Sumaryono. 2016. Antropologi Tari Dalam Perspektif Indonesia. Yogyakarta : Media Kreativa. 